\title{
Genetic Diversity among Pigeonpea (Cajanus cajan L. Millsp.) Genotypes Using Genic SSRs with Putative Function for Drought Tolerance
}

\author{
B. Sarkar, V.S.K. Chakravarthy, Y. Varalaxmi, S.K. Yadav, \\ M. Vanaja and M. Maheswari*
}

\author{
Central Research Institute for Dryland Agriculture, Santoshnagar, Hyderabad, \\ Telangana State, India \\ *Corresponding author
}

\begin{tabular}{|c|c|}
\hline & A B S T R A C T \\
\hline $\begin{array}{l}\text { K e y w o r d s } \\
\text { Molecular markers, } \\
\text { SSR, Genetic } \\
\text { diversity, } \\
\text { Drought tolerance, } \\
\text { Cluster analysis, } \\
\text { Population structure }\end{array}$ & $\begin{array}{l}\text { One hundred and thirty eight pigeonpea genotypes were analyzed for molecular genetic } \\
\text { diversity using } 34 \text { SSR markers with putative function for drought tolerance. The study } \\
\text { revealed considerable molecular genetic diversity among genotypes. Fifty two alleles were } \\
\text { obtained with } 34 \text { SSR markers while, } 1 \text { to } 3 \text { alleles was scored with an average of } \sim 1.6 \\
\text { alleles for each SSR. Three alleles were amplified by markers ASSR1, ASSR93 and } \\
\text { ASSR97. Of these, } 15 \text { SSR markers were found to be polymorphic which identified } 33 \\
\text { alleles among } 138 \text { genotypes. The average PIC value of these polymorphic SSRs was } 0.22 \\
\text { with a range of } 0.01 \text { for ASSR308 to } 0.38 \text { in ASSR97. Significant positive correlation was }\end{array}$ \\
\hline Article Info & \\
\hline $\begin{array}{l}\text { Accepted: } \\
\text { 15 March } 2017 \\
\text { Available Online: } \\
10 \text { April } 2017\end{array}$ & $\begin{array}{l}\text { diversity }\left(\mathrm{r}=0.57^{*}, \mathrm{P}<0.05\right) \text {. The average genetic distance for all pair wise comparisons } \\
\text { was estimated as } 0.27 \text {. The highest genetic distance of } 0.69 \text { was recorded between } \\
\text { genotypes PAU- } 881 \text { and LRG- } 41 \text {. Cluster analysis, done by UPGMA following Nei's } \\
\text { similarity matrix and population structure analyses grouped } 138 \text { pigeonpea genotypes into } \\
\text { seven sub-populations. }\end{array}$ \\
\hline
\end{tabular}

\section{Introduction}

Pigeonpea (Cajanus cajan L. Millsp.) is predominantly a rainfed crop grown across the world. Although it is considered as a drought tolerant crop among all grain legumes and largely grown under rainfed conditions (Keller and Ludlow, 1993) across the world, productivity is highly affected by drought if it coincide with flowering and early pod development stages (Lopez et al., 1997). There is large variation for days to maturity, ranging from extra early (90 days) to very long (300 days) among available pigeonpea germplasm. The intermittent periods of drought can affect the growth and yield of specially short-duration pigeonpea sown at the start of the rainy season. As pigeonpea is cultivated under rain-fed conditions, occurrence of drought may be episodic in varying degrees in the majority of the growing season in dry land agricultural systems. An increase in temperature above $2.5^{\circ} \mathrm{C}$, is known to convey negative effects on global agriculture on the whole. Adverse impact of drought on crop growth and development causes yield reduction. Despite several decades of intensive efforts in 
different crop improvement programmes, the yield level reached a plateau, owing to the narrow genetic base and conventional breeding procedures. The high degree of complexity associated with the genetic enhancement through breeding procedures can be successfully overcome by the employment of biotechnological interventions (Chakravarthy and Negi, 2014).

The recent advancement in pigeonpea genomic resources resulted in the development of molecular markers, genetic maps, transcriptomic or genome sequence required for molecular breeding. Discovery of molecular markers led to genetic diversity analysis using restriction fragment length polymorphism (Sivaramakrishnan et al., 2002), amplified fragment length polymorphism (Panguluri et al., 2006), random amplification of polymorphic DNA (Yadav et al., 2012), microsatellite markers (Singh et al., 2013) and DArT (Yang et al., 2006). Nevertheless, the molecular basis of most agronomic traits in pigeonpea remains unexplored due to the low level of DNA polymorphism and limited number of validated molecular markers. The presence of genetic diversity plays a vital role for a successful breeding program. Genetic diversity is essential prerequisite in breeding for drought tolerance, increased yields, wider adaptation and desirable quality. Earlier studies on genetic diversity with limited number of genotypes has been reported in pigeonpea viz., 36 elite cultivated genotypes (Singh et al., 2013), 45 genotypes (Datta et al., 2013), 16 cultivars and 2 wild relatives (Yadav et al., 2012), 15 genotypes (Shende and Raut, 2013), 49 genotypes (Rekha et al., 2011), 88 accessions (Songok et al., 2010), 16 genotypes (Singh et al., 2008) and 14 genotypes (Chakraborty et al., 2013). These studies however, focused on studying overall genetic diversity among pigeonpea germplasm using genic and genomic SSRs not specifically SSR markers related to drought tolerance.

The objective of the present investigation was to study the level of molecular genetic diversity and population structure among pigeonpea cultivars and germplasm collection using genic SSR markers linked with putative function for drought tolerance.

\section{Materials and Methods}

\section{Plant material}

A total of one hundred and thirty eight pigeonpea genotypes, adapted to different climatic conditions, were received from Indian Institute of Pulses Research, Kanpur, India. Information on sources of origin of these genotypes is given in Online Resource 1. The genotypes included in the study are mostly the released varieties for different production areas in India; advanced breeding lines and germplasm accessions from Regional Research Station, National Bureau of Plant Genetic Resources, Hyderabad. All these genotypes were sown in two rows of $2.5 \mathrm{~m}$ plot, with a row to row spacing of $90 \mathrm{~cm}$ and plant to plant spacing of $30 \mathrm{~cm}$ in augmented block design at CRIDA, Hyderabad. The recommended fertilizer doses and agronomic operations were carried out for adequate protection against pests, diseases and weeds.

\section{DNA extraction and PCR}

Genomic DNA was extracted following CTAB method (Paterson et al., 1993) with minor modifications from top most fully expanded leaf samples of four-week old plants for each genotype. Thirty four genic SSR markers previously reported by Dutta et al., (2011) were used to amplify the DNA for genotyping. The PCR reaction contained 1.0 unit of Taq DNA polymerase, 1X Taq buffer 
and $200 \mu \mathrm{M}$ of each dNTP. Approximately, 50ng of genomic DNA and 10 picomoles of each primer were used and the volume was made up to $20 \mu 1$ using sterile distilled water. DNA amplification was carried out in a Thermal Cycler (Applied Biosystems) with a PCR profile comprised an initial denaturation for $5 \mathrm{~min}$ at $94^{\circ} \mathrm{C}$ followed by 35 cycles with a denaturing step at $94^{\circ} \mathrm{C}$ for 45 seconds, a primer annealing at $60^{\circ} \mathrm{C}$ for 45 seconds and an extension at $72^{\circ} \mathrm{C}$ for 45 seconds. After the last cycle, a final extension was carried out at $72^{\circ} \mathrm{C}$ for $5 \mathrm{~min}$. Amplified PCR products were resolved through electrophoresis at 80 volts for one hour and 30 minutes in $4 \%$ agarose gel containing $0.5 \mu \mathrm{g} / \mathrm{ml}$ ethidium bromide and photographed under ultraviolet light with Vilber Loumat gel documentation system. The SSR amplification profiles were scored based on the size (bp) of the amplicons obtained among 138 genotypes using Biovision Software, USA.

\section{Statistical analyses}

Gene diversity, heterozygosity and polymorphism information content (PIC) for each of the primer pair was calculated using Power Marker v.3.25 software (Liu and Muse, 2005). Genetic distances between the genotypes were also calculated (Nei, 1973). Phylogenetic tree was constructed using UPGMA (unweighted pair-group method using arithmetic average) by neighbor-joining method and dendogram was generated by MEGA software version 5.0 (Tamura et al., 2011). The STRUCTURE 2.3.4 (Pritchard et al., 2000; Falush et al., 2003) software was used to detect population structure and assign individuals to subpopulations following model based on clustering by Bayesian approach which identifies clusters based on a fit to Hardy-Weinberg linkage equilibrium. The population structure analysis was used to infer historical lineages that show grouping of similar genotypes. For each cluster K, five replications were run where each run was implemented with a burn-in period of 100,000 steps followed by 100,000 Monte Carlo Markov Chain replicates derived for each $\mathrm{K}$ and then plotted to find the plateau of the $\Delta \mathrm{K}$ values (Evanno et al., 2005).

\section{Results and Discussion}

Research for development of drought tolerant crops is of urgent priority, as water stress is one of the main reasons for the major crop losses globally and is expected to exacerbate due to projected climate change impacts. Pigeonpea being an important source of dietary protein and a major legume in the arid and semi-arid regions, may be adversely affected due to climate change unless efforts made to develop tolerant cultivars. Identification of diverse parents is essentially required before carrying out successful crop improvement program (Tidke and Ranawade, 2017). In this section we discuss the results pertaining to molecular characterization of 138 pigeonpea genotypes adapted to diverse climatic conditions using SSR markers associated with putative function for drought tolerance.

\section{Polymorphism and marker efficiency}

Pigeonpea genotypes characterized using 34 SSR markers revealed 15 SSRs as polymorphic $\quad(\sim 44 \%)$ while 19 as monomorphic $(\sim 66 \%)$. The polymorphic SSRs was used to examine the degree of genetic variation among pigeonpea genotypes. List of polymorphic SSRs and their predicted function of genes linked with these SSRs, amplicon size was given in Table 1. A total of fifty two alleles were obtained with 34 SSR markers and number of alleles scored for each SSR loci ranged from 1 to 3 with an average of $~ 1.6$ alleles per primer pair. Three alleles were amplified by ASSR1, ASSR93 and ASSR97. The amplification profile of 
ASSR93 was given in Fig. 1. The PIC value of SSRs ranged from 0.01 (ASSR308) to 0.38 (ASSR97) with an average being 0.22 (Table 2). Among these 15 polymorphic SSR markers, 8 SSRs viz., ASSR1, ASSR3, ASSR8, ASSR19, ASSR93, ASSR97, ASSR280 and ASSR648 gave PIC >0.25 with an average of 0.32 and 19 alleles with an average of 2.38 alleles/primer. The major allele frequencies among the primers tested varied between 0.59 (ASSR19) to 0.99 (ASSR213) with an average of 0.82. On the other hand, gene diversity varied from 0.01 to 0.48 with an average of 0.26 .

The study revealed a total of 52 alleles using 34 SSR markers among 138 genotypes which was similar to findings made by Singh et al., (2013), who reported 59 alleles using 60 SSR markers among 36 genotypes. The PIC of SSRs obtained in our study was relatively higher than those reported by Khalekar et al., (2014) and Datta et al., (2013). Several other workers also reported different level of genetic diversity in pigeonpea (Panguluri et al., 2006; Yang et al., 2006; Singh et al., 2013). This variation in genetic diversity is probably attributed to diversification in morphology, use of common ancestors for the development of new cultivars (Panguluri et al., 2006; Yang et al., 2006). The present study also revealed significant positive correlation between PIC values with number of alleles amplified per primer $\left(\mathrm{r}=0.58^{*}, \mathrm{P}<\right.$ $0.05)$ and gene diversity $\left(\mathrm{r}=0.99^{* *}, \mathrm{P}<\right.$ 0.01 ), and between allele number and gene diversity $\left(r=0.57^{*}, \mathrm{P}<0.05\right)$.

\section{Genetic similarity among genotypes}

Genetic distance among the 138 pigeonpea genotypes was calculated to identify the relatedness between genotypes. The genetic distance measured through polymorphic SSRs revealed varying degree of genetic relatedness among the pigeonpea genotypes. The average genetic distance for all pair wise comparisons was 0.27 . The highest genetic distance of 0.69 was recorded between genotypes PAU-881 and LRG-41; PT-00-022 and LRG-41, followed by BWR-153 and RVK-281; RJR292 and GT-1 which exhibited genetic distance of 0.67 . Whereas, 10 genotype combinations viz., CO-6 and AL-1578, GT100 and AL-1578, ICP-84031 and AL-1578, UPAS-120 and LRG-41, AL-1816 and RVK278, VKG-14151 and RVK-281, RVK-278 and AL-1578, PG-12 and AL-1816, Pusa-84 and CO-5, Pusa-84 and GRG-2761 had genetic distance of 0.64 .

\section{Cluster analysis}

The cluster analysis based on Power marker software using polymorphic SSR markers resulted in separation of the genotypes into two major clusters (Fig. 2). Cluster II was larger comprising of 97 genotypes. Further, this cluster was sub-divided into five subclusters with number of genotypes per cluster ranging from 6 to 35. On the other hand, cluster I is divided into two sub-clusters, consisting of 31 and 10 genotypes respectively.

\section{Population structure analysis}

Population structure analysis divided 138 pigeonpea genotypes into seven different groups, assuming low levels of admixture between subpopulations (Fig. 3 and Table 3). List of pigeonpea genotypes corresponding to different groups is given in Online Resource 2 . The number of genotypes ranged from 15 in group $G_{6}$ to 29 in group $G_{2}$. Groups $G_{1}$ and $\mathrm{G}_{3}$ comprised of 17 genotypes each whereas, groups $\mathrm{G}_{5}$ and $\mathrm{G}_{7}$ contained 19 genotypes each. On the other hand group $\mathrm{G}_{4}$ had 22 genotypes. Among the genotypes tested, higher gene diversity was displayed within $\mathrm{G}_{6}$ $(0.25)$ followed by $\mathrm{G}_{4}(0.23)$ and $\mathrm{G}_{1}(0.22)$, whereas a low level (0.06) of gene diversity was displayed by $\mathrm{G}_{7}$ (Table 4). 
Table.1 Details of 34 SSRs used in the present study and predicted function of their genes

\begin{tabular}{|c|c|c|c|c|}
\hline $\begin{array}{l}\text { Sl. } \\
\text { No. }\end{array}$ & $\begin{array}{l}\text { SSR } \\
\text { marker }\end{array}$ & SSR motif & Predicted function & $\begin{array}{l}\text { Amplicon } \\
\text { Size (bp) }\end{array}$ \\
\hline 1 & ASSR-1 & $(\mathrm{GA}) 10$ & Putative Kinase & $100-120$ \\
\hline 2 & ASSR-3 & $(\mathrm{AGAAAG}) 5$ & $\begin{array}{l}\text { Cytochrome P450 Possessing cinnamate 4- } \\
\text { hydroxylase activity }\end{array}$ & $130-150$ \\
\hline 3 & ASSR-8 & (AGA)9 & $\mathrm{Cu} / \mathrm{Zn}$-Superoxide dismutase (SOD) & $140-150$ \\
\hline 4 & ASSR-19 & (TGTTCA)5 & DNA binding protein (Homeodomain) & $150-160$ \\
\hline 5 & ASSR-23 & (CCTTCT)5 & Acetyltransferase & $150-170$ \\
\hline 6 & ASSR-25 & $(\mathrm{GA}) 10$ & Ser/Thr protein kinase & 180 \\
\hline 7 & ASSR-36 & (TC)14 & Global transcription factor group & 160 \\
\hline 8 & ASSR-39 & (GAA)7 & Cyclin & 180 \\
\hline 9 & ASSR-49 & $(\mathrm{TC}) 10$ & calmodulin binding protein & 180 \\
\hline 10 & ASSR-66 & (CT)12 & Hypothetical protein & 180 \\
\hline 11 & ASSR-70 & (GGTAGA)6 & Gamma glutamylcyclotransferase & $170-200$ \\
\hline 12 & ASSR-91 & (GGTTA)5 & Hypothetical protein & 120 \\
\hline 13 & ASSR-93 & (CATTTG)5 & Hypothetical protein & $160-180$ \\
\hline 14 & ASSR-97 & (ATGGAC)8 & Chloroplast targeted copper chaperone & $150-190$ \\
\hline 15 & ASSR-121 & $(\mathrm{TCT}) 8$ & Ethylene responsive transcription factor & 180 \\
\hline 16 & ASSR-138 & $(\mathrm{CTT}) 8$ & r2r3-myb transcription factor & 160 \\
\hline 17 & ASSR-148 & $(\mathrm{CAA}) 7$ & Ethylene-responsive transcription factor & $110-120$ \\
\hline 18 & ASSR-163 & (TCA) 8 & Heat shock protein binding & 210 \\
\hline 19 & ASSR-168 & (TCA)9 & Heat shock protein & $150-160$ \\
\hline 20 & ASSR-213 & $(\mathrm{AGG}) 7$ & Mitogen-activated protein kinase 1 & $150-160$ \\
\hline 21 & ASSR-275 & (TAAT)5 & MYB transcription factor MYB48 & 130 \\
\hline 22 & ASSR-279 & (ACAGGA)7 & $\begin{array}{l}\text { Senescence-inducible chloroplast stay-green } \\
\text { protein-1 }\end{array}$ & $180-190$ \\
\hline 23 & ASSR-280 & (TGGCAT)5 & $\begin{array}{l}\text { Senescence-inducible chloroplast stay-green } \\
\text { protein }\end{array}$ & $160-170$ \\
\hline 24 & ASSR-304 & (GTT)7 & Ethylene responsive transcription factor & 110 \\
\hline 25 & ASSR-308 & (TC) 10 & Serine/threonine protein kinase & $150-160$ \\
\hline 26 & ASSR-388 & $(\mathrm{CCA}) 7$ & No homology & 150 \\
\hline 27 & ASSR-538 & (TC)9 & MYB transcription factor MYB34 & 150 \\
\hline 28 & ASSR-609 & $(\mathrm{ACC}) 6$ & Leucine Rich family protein & 190 \\
\hline 29 & ASSR-648 & (GAT)6 & Protein of early response to dehydration & $150-160$ \\
\hline 30 & ASSR-973 & (TTG)6 & Ethylene insensitive protein & 150 \\
\hline 31 & ASSR-1092 & $(\mathrm{CGG}) 6$ & $\begin{array}{l}\text { Serine/threonine protein kinase catalytic } \\
\text { domain }\end{array}$ & 160 \\
\hline 32 & ASSR-1214 & $(\mathrm{ACA}) 6$ & WRKY family transcription factor & 170 \\
\hline 33 & ASSR-1217 & (GGA)6 & WRKY family transcription factor & 190 \\
\hline 34 & ASSR-1639 & (AAT)6 & Senescence-associated protein & 150 \\
\hline
\end{tabular}


Table.2 Number of alleles, gene diversity and PIC of polymorphic microsatellite markers

\begin{tabular}{|l|l|c|c|c|c|c|}
\hline Sl. No. & Marker & $\begin{array}{c}\text { Number of } \\
\text { Alleles }\end{array}$ & $\begin{array}{c}\text { Amplicon } \\
\text { Size (bp) }\end{array}$ & $\begin{array}{c}\text { Gene } \\
\text { Diversity }\end{array}$ & PIC & $\begin{array}{c}\text { Major } \\
\text { allele } \\
\text { frequency }\end{array}$ \\
\hline 1 & ASSR1 & 3 & $100-120$ & 0.39 & 0.33 & 0.75 \\
\hline 2 & ASSR3 & 2 & $130-150$ & 0.31 & 0.26 & 0.81 \\
\hline 3 & ASSR8 & 2 & $140-150$ & 0.29 & 0.25 & 0.83 \\
\hline 4 & ASSR19 & 2 & $150-160$ & 0.48 & 0.37 & 0.59 \\
\hline 5 & ASSR23 & 2 & $150-170$ & 0.28 & 0.24 & 0.83 \\
\hline 6 & ASSR70 & 2 & $170-200$ & 0.20 & 0.18 & 0.89 \\
\hline 7 & ASSR93 & 3 & $160-180$ & 0.45 & 0.38 & 0.69 \\
\hline 8 & ASSR97 & 3 & $150-190$ & 0.48 & 0.38 & 0.62 \\
\hline 9 & ASSR148 & 2 & $110-120$ & 0.22 & 0.20 & 0.87 \\
\hline 10 & ASSR168 & 2 & $150-160$ & 0.12 & 0.11 & 0.94 \\
\hline 11 & ASSR213 & 2 & $150-160$ & 0.01 & 0.01 & 0.99 \\
\hline 12 & ASSR279 & 2 & $180-190$ & 0.04 & 0.04 & 0.98 \\
\hline 13 & ASSR280 & 2 & $160-170$ & 0.38 & 0.31 & 0.75 \\
\hline 14 & ASSR308 & 2 & $150-160$ & 0.01 & 0.01 & 0.99 \\
\hline 15 & ASSR648 & 2 & $150-160$ & 0.31 & 0.26 & 0.81 \\
\hline & Average & 2.20 & & 0.26 & 0.22 & 0.82 \\
\hline
\end{tabular}

Fig.1 PCR amplification pattern of 138 pigeonpea genotypes using ASSR93 primers. M100=100bp DNA size marker
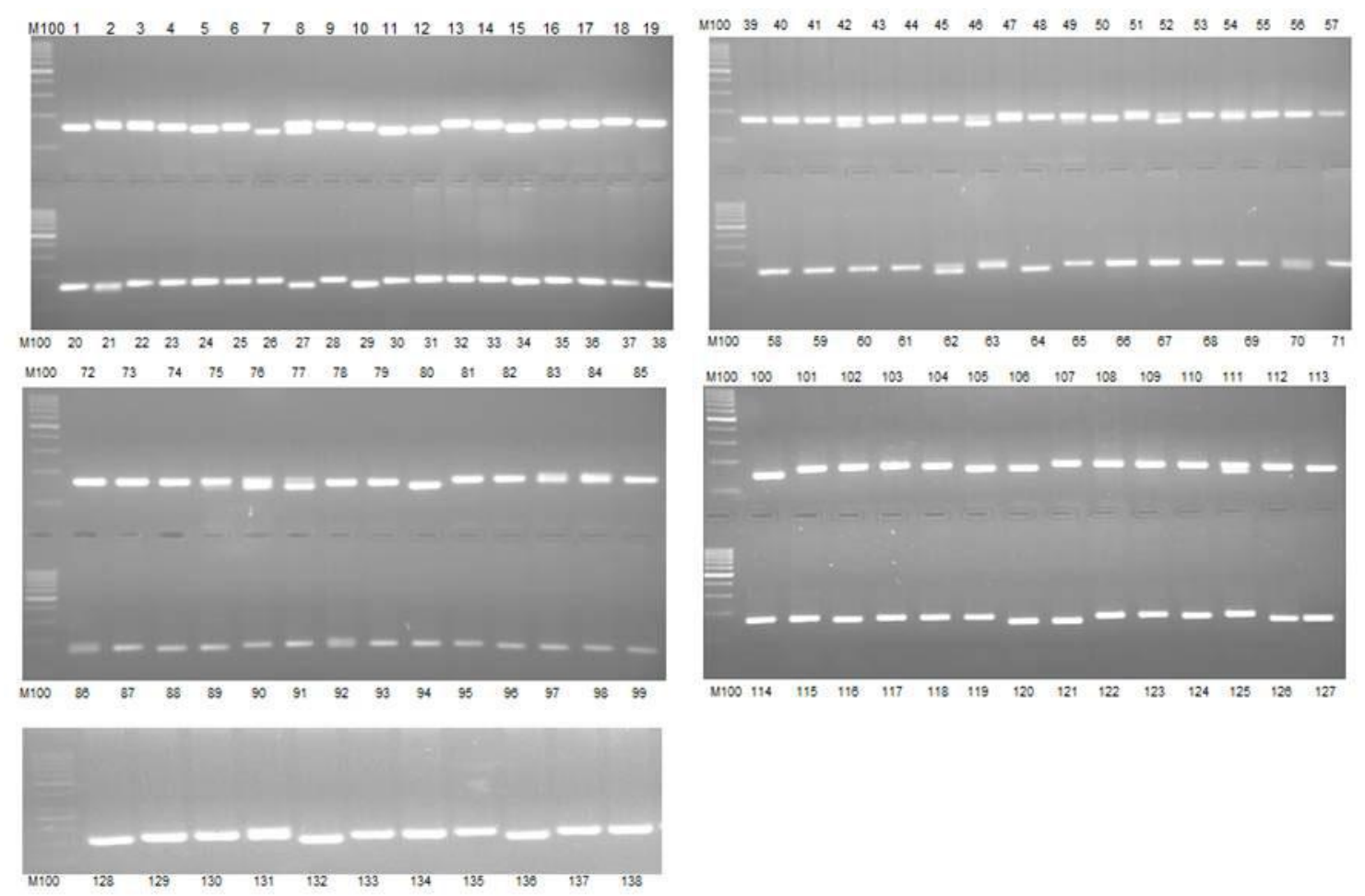
Table.3 list of pigeonpea genotypes corresponding to a group in population structure analysis $\mathrm{G}_{1}: 54-63 ; \mathrm{G}_{2}: 105-44 ; \mathrm{G}_{3}: 88-116 ; \mathrm{G}_{4}$ : $129-4 ; \mathrm{G}_{5}: 22-114 ; \mathrm{G}_{6}: 134-123 ; \mathrm{G}_{7}: 33-118$

\begin{tabular}{|c|c|c|c|c|c|c|c|c|c|c|c|c|c|}
\hline \multicolumn{2}{|r|}{$\mathbf{G}_{1}$} & \multicolumn{2}{|r|}{$\mathbf{G}_{2}$} & \multicolumn{2}{|r|}{$\mathbf{G}_{3}$} & \multicolumn{2}{|r|}{$\mathbf{G}_{4}$} & \multicolumn{2}{|r|}{$\mathbf{G}_{5}$} & \multicolumn{3}{|c|}{$\mathbf{G}_{6}$} & $\mathbf{G}_{7}$ \\
\hline 54 & ICP84031 & 105 & RVK272 & 88 & Pusa855 & 129 & TS3R & 22 & BDN708 & 134 & Vipula & 33 & C11 \\
\hline 55 & ICPL151 & 17 & BDN2 & 66 & LRG30 & 138 & WRP1 & 85 & PT221 & 130 & TV1 & 136 & WRG27 \\
\hline 57 & ICPL87 & 61 & Jamadhar local & 60 & JA4 & 25 & BPG512 & 117 & RVK286 & 35 & $\mathrm{CO5}$ & 132 & Vamban1 \\
\hline 87 & Pusa84 & 26 & BPG513 & 68 & LRG41 & 34 & Chaple & 42 & GRG2006 & 9 & AL1816 & 48 & GS1 \\
\hline 50 & GT100 & 120 & SNJ201151 & 56 & ICPL85063 & 51 & Gulyal red & 40 & GP101 & 19 & BDN20086 & 93 & RJR232 \\
\hline 83 & PT002251 & 101 & RJR353 & 96 & RJR292 & 62 & JKM189 & 126 & TAT9903 & 122 & SNJ201187 & 2 & AK101 \\
\hline 81 & PSRJ13147 & 31 & BSMR853 & 72 & NDA2 & 131 & UPAS120 & 11 & AL1855 & 73 & Paras & 91 & RJR185 \\
\hline 38 & DA11 & 41 & GRG0811 & 13 & Amar & 82 & PT0022 & 6 & AL15 & 70 & Manak & 1 & $\mathrm{AK} 022$ \\
\hline 52 & HY3C & 65 & Karitogari & 109 & RVK277 & 74 & PAU881 & 59 & ICPL8863 & 89 & Pusa991 & 58 & ICPL88039 \\
\hline 115 & RVK283 & 24 & BPG109 & 36 & CO6 & 10 & AL1817 & 3 & AKP1 & 27 & BRG1 & 90 & RJR121 \\
\hline 137 & WRG53 & 97 & RJR302 & 37 & CORG9701 & 75 & PBJ55C233 & 124 & T1515 & 49 & GT1 & 92 & RJR223 \\
\hline 133 & Vamban2 & 119 & SNJ2011103 & 39 & GL1139 & 18 & BDN200812 & 128 & TS3 & 69 & MA3 & 104 & RJR81 \\
\hline 64 & $\mathrm{~K} 2$ & 98 & RJR314 & 127 & TJT501 & 135 & VKG14151 & 16 & Banas & 113 & RVK281 & 102 & RJR358 \\
\hline 110 & RVK278 & 80 & PSR13229 & 47 & GRG815 & 30 & BSMR736 & 20 & BDN20088 & 5 & AKT9915 & 46 & GRG333 \\
\hline 77 & PH12 & 79 & PSR13227 & 8 & AL1757 & 12 & AL201 & 84 & PT0431 & 123 & SNJ201197 & 67 & LRG38 \\
\hline 76 & PG12 & 108 & RVK275 & 15 & Azad & 125 & TAT10 & 45 & GRG281 & & & 103 & RJR67 \\
\hline 63 & JKM7 & 121 & SNJ201171 & 116 & RVK285 & 86 & Pusa33 & 43 & GRG20091 & & & 100 & RJR33 \\
\hline & & 94 & RJR246 & & & 7 & AL1578 & 29 & BSMR533 & & & 28 & Brisha arhar \\
\hline & & 21 & BDN20089 & & & 71 & NDA1 & 114 & RVK282 & & & 118 & SKM187 \\
\hline & & 112 & RVK280 & & & 32 & BWR153 & & & & & & \\
\hline & & 99 & RJR315 & & & 53 & ICP13673 & & & & & & \\
\hline & & 95 & RJR263 & & & 4 & AKT881 & & & & & & \\
\hline & & 107 & RVK274 & & & & & & & & & & \\
\hline & & 23 & Bennur local & & & & & & & & & & \\
\hline & & 111 & RVK279 & & & & & & & & & & \\
\hline & & 78 & PRG158 & & & & & & & & & & \\
\hline & & 14 & Asha & & & & & & & & & & \\
\hline & & 106 & RVK273 & & & & & & & & & & \\
\hline & & 44 & GRG2761 & & & & & & & & & & \\
\hline
\end{tabular}


Table.4 Summary statistics for the whole group of pigeonpea genotypes and subpopulations detected by structure analysis based on 15 polymorphic SSR markers

\begin{tabular}{lcccccccc}
\hline Statistics & Overall & G1 & G2 & G3 & G4 & G5 & G6 & G7 \\
\hline Sample size & 138 & 17 & 29 & 17 & 22 & 19 & 15 & 19 \\
Total number of alleles & 33 & 25 & 24 & 25 & 27 & 22 & 28 & 19 \\
Mean number of alleles & 2.20 & 1.67 & 1.60 & 1.67 & 1.80 & 1.47 & 1.87 & 1.27 \\
Major allele frequency & 0.82 & 0.84 & 0.93 & 0.87 & 0.84 & 0.91 & 0.82 & 0.96 \\
Gene diversity & 0.26 & 0.22 & 0.10 & 0.19 & 0.23 & 0.13 & 0.25 & 0.06 \\
\hline
\end{tabular}

Fig.2 UPGMA tree using Nei similarity coefficient

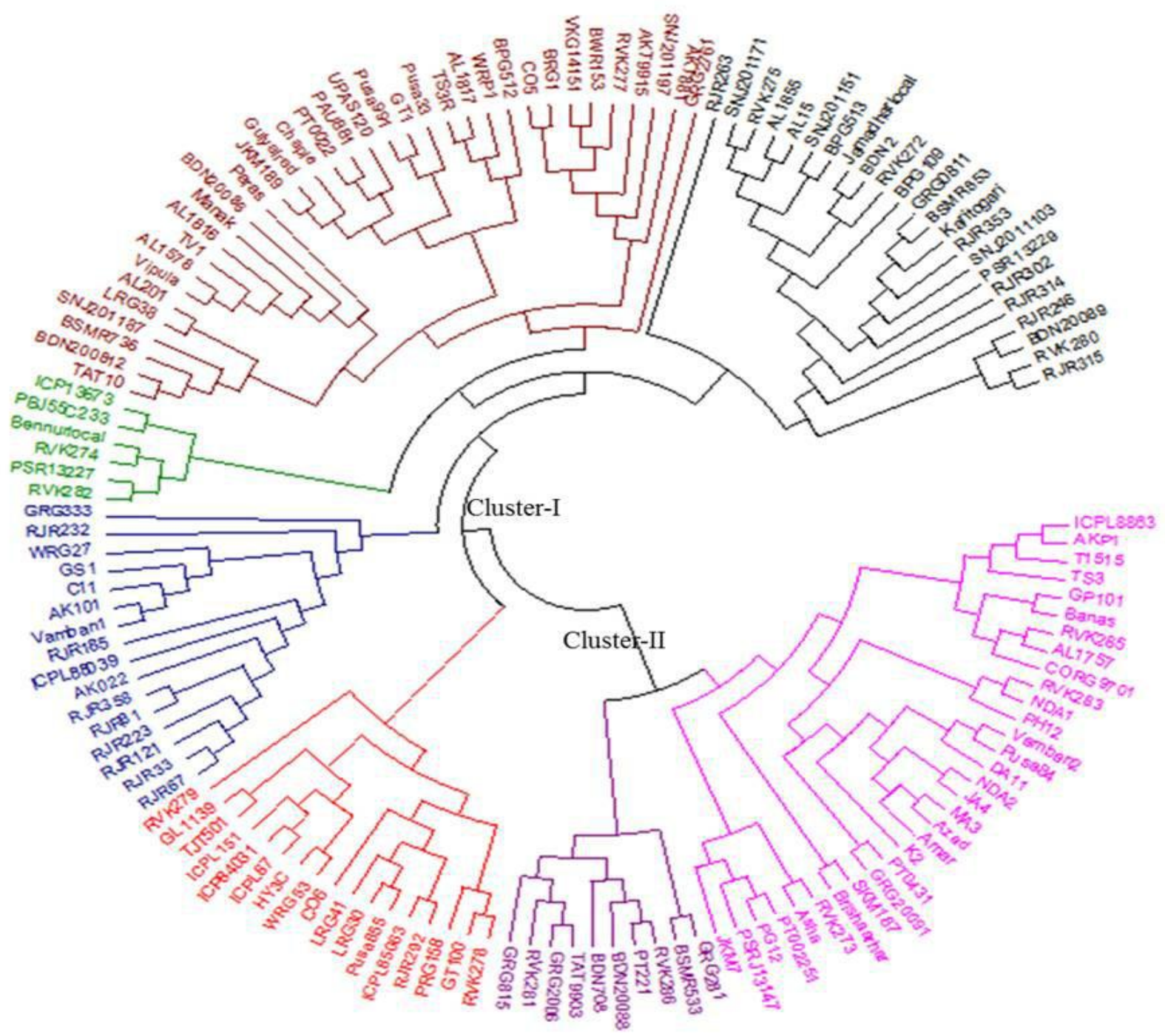


Fig.3 Population structure analysis. The y-axis is the subgroup membership, and the $\mathrm{x}$-axis is the accessions. $G\left(G_{1}\right.$ to $\left.G_{7}\right)$ stands for a subpopulation
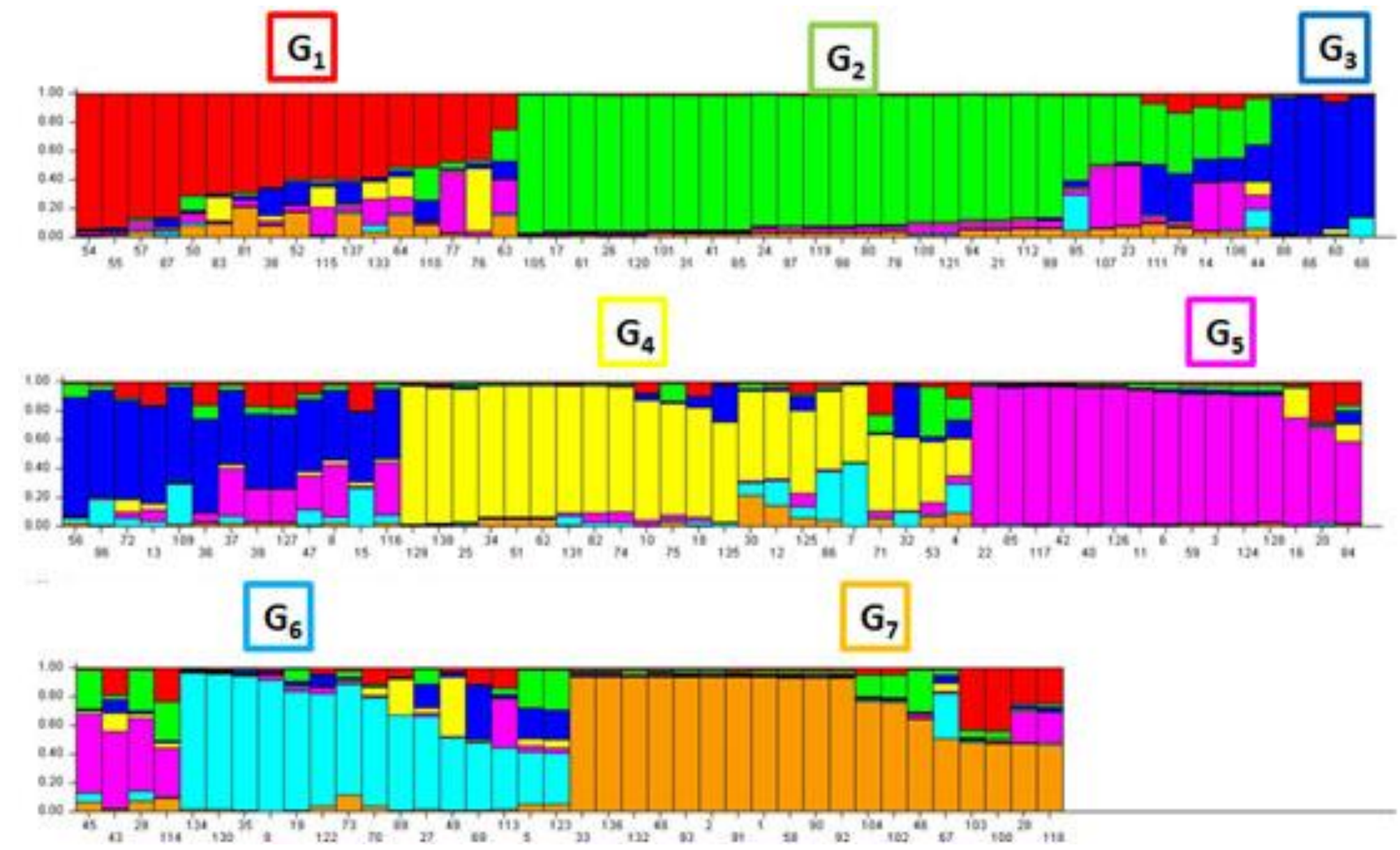
Population structure analysis using SSR data revealed seven subpopulations, with varying degrees of admixture among subpopulations (Fig. 3). Structure analysis indicated the patterns of allele sharing among different pigeonpea genotypes from diverse agroclimatic regions and large scale sharing of alleles among the genotypes. In addition, UPGMA tree using neighbor joining also grouped the genotypes into seven subpopulations. The clusters found in structure analysis were almost consistent with the cluster analysis following UPGMA method using Nei similarity coefficient. Most of the genotypes were classified into the corresponding sub-population and branch was similar with a few exceptions.

Molecular analysis using drought linked genic SSR provided a good insight of genetic diversity and population structure among pigeonpea materials used in the present investigation. These findings will be useful in selection of diverse genotypes for development of new cultivars with adaptation to a broad range of environments. Further, the genotypes producing specific amplicons with SSR markers can be used for cultivar identification.

\section{Acknowledgements}

This work was carried out under the ICAR project on National Innovations on Climate Resilient Agriculture (NICRA). Authors are thankful to the Project Coordinator, MULLaRP, Indian Institute of Pulses Research Kanpur (IIPR) and In-Charge, National Bureau of Plant Genetic Resources (NBPGR) Regional Station, Hyderabad for providing seed materials.

\section{References}

Chakraborty, S., Aher, B., Sasidharan, N., Trivedi, R., Ravikiran, R. and Shah, A. 2013. Assessment of genetic purity and phylogeny in pigeon pea (Cajanus cajan) genotypes by RAPD and SSR markers. Int. J. Agric. Environ. Biotechnol., 6: 55-60.

Chakravarthy, V.S.K. and Negi, P.S. 2014. Enhanced in vitro regeneration from seedling explants of a medicinally important leguminous tree (Albizia lebbeck Benth.). Int. J. Curr. Microbiol. App. Sci., 3: 65-73.

Datta, S., Singh, P., Mahfooz, S., Patil, P.G., Chaudhary, A.K., Agbagwa, I.O. and Nadarajan, N. 2013. Novel genic microsatellite markers from Cajanus scarabaeoides and their comparative efficiency in revealing genetic diversity in pigeonpea. J. Genet., 92: e24-e30.

Dutta, S., Kumawat, G., Singh, B.P., Gupta, D.K., Singh, S., Dogra, V., Gaikwad, K., Sharma, T.R., Raje, R.S., Bandhopadhya, T.K., Datta, S., Singh, M.N., Bashasab, F., Kulwal, P., Wanjari, K.B., Varshney, R.K., Cook, D.R. and Singh, N.K. 2011. Development of genic-SSR markers by deep transcriptome sequencing in pigeonpea (Cajanus cajan (L.) Millspaugh). BMC Plant Biol., 11: 17.

Evanno, G., Regnaut, S. and Goudet, J. 2005. Detecting the number of clusters of individuals using the software STRUCTURE: a simulation study. Mol. Ecol., 14: 2611-2620.

Falush, D., Stephens, M. and Pritchard, J.K. 2003. Inference of population structure: Extensions to linked loci and correlated allele frequencies. Genetics, 164: 15671587.

Keller, F. and Ludlow, M.M. 1993. Carbohydrate metabolism in drought stressed leaves of pigeonpea (Cajanus cajan). J. Exp. Bot., 44: 1351-1359.

Khalekar, G.D., Akhare, A.A., Gahukar, S.J., Singh, N.K. and Kumar, M. 2014. Identification of simple sequence repeat markers associated with wilt resistance in pigeonpea. J. Environ. Biol., 35: 955-960.

Liu, K. and Muse, S.V. 2005. PowerMarker, an integrated analysis environment for genetic marker analysis. Bioinformatics, 21: 21282129.

Lopez, F.B., Chauhan, Y.S. and Johansen, C. 1997. Effects of timing of drought stress on 
leaf area development and canopy light interception of short-duration pigeonpea. $J$. Agron. Crop Sci., 178: 1-7.

Nei, M. 1973. The theory and estimation of genetic distance. In: Morton NE (eds), Genetic Structure of Populations. University Press of Hawaii, Honolulu, pp. 45-54.

Panguluri, S.K., Janaiah, K., Govil, J.N., Kumar, P.A. and Sharma, P.C. 2006. AFLP fingerprinting in pigeonpea (Cajanus cajan (L.) Millsp.) and its wild relatives. Gene. Res. Crop Evol., 53: 523-531.

Paterson, A.H., Brubaker, C.L. and Wendel, J.F. 1993. A rapid method for extraction of cotton (Gossypium ssp) genomic DNA suitable for RFLP or PCR analysis. Plant Mol. Biol. Rep., 11: 122-127.

Pritchard, J.K., Stephens, M. and Donnelly, P. 2000. Inference of population structure using multilocus genotype data. Genetics, 155: 945-959.

Rekha, R., Prasanthi, L., Sekhar, M.R., Latha, P. and Sudhakar, S. 2011. Genetic diversity in pigeonpea [Cajanus cajan (L.) Millsp]. Legume Res., 34: 139-142.

Shende, S. and Raut, A. 2013. Analysis of genetic diversity in pigeon pea (Cajanus cajan) by using PCR based molecular marker. Rec. Res. Sci. Technol., 5: 20-23.

Singh, A.K., Rai, V.P., Chand, R., Singh, R.P. and Singh, M.N. 2013. Genetic diversity studies and identification of SSR markers associated with Fusarium wilt (Fusarium udum) resistance in cultivated pigeonpea (Cajanus cajan). J. Genet., 92: 273-280.

Singh, S., Singh, K.N., Kant, R., Mehfooz, S. and Dutta, S. 2008. Assessment of genetic diversity among pigeonpea genotypes using SSR markers. Indian Journal of Genetics, 68: 255-260.

Sivaramakrishnan, S., Kannan, S. and Reddy, L.J. 2002. Diversity in selected wild and cultivated species of pigeonpea using RFLP of mtDNA. Euphytica, 125: 21-28.

Songok, S., Ferguson, M., Muigai, A.W. and Silim, S. 2010. Genetic diversity in pigeonpea [Cajanus cajan (L.) Millsp.] landraces as revealed by simple sequence repeat markers. Afr. J. Biotechnol., 9: 32313241.

Tamura, K., Peterson, D., Peterson, N., Stecher, G., Nei, M. and Kumar, S. 2011. MEGA5, molecular evolutionary genetics analysis using maximum likelihood, evolutionary distance, and maximum parsimony methods. Mol. Biol. Evol., 28: 2731-2739.

Tidke, S.D. and Ranawade, P.S. 2017. Genetic Analysis and RAPD Polymorphism in Wheat (Triticum aestivum L.) Genotypes. Int. J. Curr. Microbiol. App. Sci., 6: 239246.

Yadav, K., Yadav, S.K., Yadav, A., Pandey, V.P. and Dwivedi, U.N. 2012. Genetic diversity of pigeonpea (Cajanus cajan (L.) Millsp.) cultivars and its wild relatives using randomly amplified polymorphic DNA (RAPD) markers. Amer. J. Plant Sci., 3: 322-330.

Yang, S., Pang, W., Ash, G., Harper, J., Carling, J., Wenzl, P., Huttner, E., Zong, X. and Kilian, A. 2006. Low level of genetic diversity in cultivated pigeonpea compared to its wild relatives is revealed by diversity arrays technology. Theor. Appl. Genet., 113: 585-595.

\section{How to cite this article:}

Sarkar, B., V.S.K. Chakravarthy, Y. Varalaxmi, S.K. Yadav, M. Vanaja and Maheswari, M. 2017. Genetic Diversity among Pigeonpea (Cajanus cajan L. Millsp.) Genotypes Using Genic SSRs with Putative Function for Drought Tolerance . Int.J.Curr.Microbiol.App.Sci. 6(4): 1804-1814. doi: https://doi.org/10.20546/ijcmas.2017.604.216 